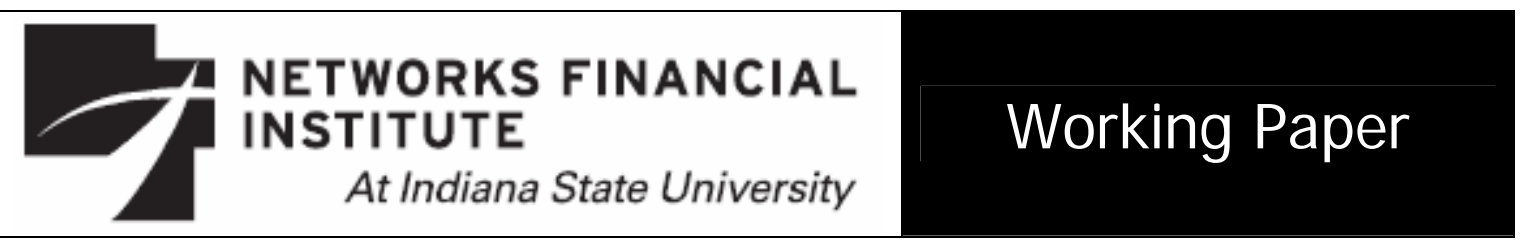

2007-WP-29

November 2007

\title{
Approaches to Business I ncubation: A Comparative Study of the United States, China and Brazil Aruna Chandra
}

Abstract: The purpose of this paper is to describe and compare key elements of the business incubation landscape in the United States, China and Brazil in order to provide an understanding of the similarities and differences in incubation systems across the three countries, as well as the opportunities and challenges inherent in the macroenvironmental and institutional environments for new business creation. Incubator models are described and compared along key dimensions which include strategic objectives, incubator financing/incubator sponsorship and its impact on strategy, and the incubator's service mix with an emphasis on financial services provided by incubators to client firms. The role of government and its impact on incubator strategy as well as its role in supporting the environment for new business creation is discussed. A study of incubation and the innovation ecosystem in these leading incubation markets ought to have relevance not just in cross cultural comparative settings, but also to global incubation in both developed and developing countries, in terms of policy and practice.

About the Author: Aruna Chandra, Associate Professor of Management at the College of Business, Indiana State University, received her Ph.D. in Strategy and International Business from Kent State University in 2000. Her book, Business India: Finding Opportunities in this Big Emerging Market, was published in 2002 by Paramount Market Publishing. Her current research interests include knowledge management in entrepreneurial firms and approaches to business incubation in different countries. Dr. Chandra visited China in 2004 on a State Department grant to lecture at Liaoning University and to interview and collect archival data from business incubators located in major cities. In 2006 she traveled to Peru, Bolivia, Chile, Argentina and Brazil to interview business incubators in the South American context. She has lectured at universities in China, India and Greece and has published research on emerging market business strategies in multiple journals.

Keywords: Business incubators, new business creation, incubator financing/ sponsorship, incubator financial services.

The views expressed are those of the individual author and do not necessarily reflect official positions of Networks Financial Institute. Please address questions regarding content to Aruna Chandra at achandrasek@isugw.indstate.edu. Any errors or omissions are the responsibility of the author.

The author is grateful for the generous support of Networks Financial Institute and Indiana State University. She would like to thank Connie Vedovello, Christiano Becker, Eurico Ferreira, Jose Assuncao, Vinicius Lagus in Brazil and Wei He, Qi Jiao, Hongwei Liu, Chao-Wei Liu, Jiuping Wang and YuanYuan Xing in China and numerous other individuals for their assistance with interviews, interpretation, translation and incubator contacts and Drs. Tim Fealey, David Griffith and John Ryans for their help in developing the research protocol. 


\section{Approaches to Business I ncubation: A Comparative Study of the United States, China and Brazil Aruna Chandra}

\section{Introduction}

Business incubators are viewed by many country governments as dynamic tools for fostering new ventures with the macro objective of economic development and job creation. Small businesses are engines of growth in many dynamic economies. The research in areas related to business incubators is still in its nascent stages, primarily due to the fact that business incubation as a form of support did not gain currency until the late 1980s and 1990s in many parts of the world. Incubation is a vital component of an entrepreneurial infrastructure and this concept is moving mainstream with increased interest and awareness of the power of this support mechanism.

As business incubators gain ubiquity in various parts of the developed and developing world, incubator models have evolved in sophistication, variety and complexity. The services that are offered and the configurations they take vary widely, since they are highly sensitive to local environmental conditions and to the unique entrepreneurial ecosystem in that country (Lalkaka, 2002). While incubators have been in existence in the United States since the 1960s, business incubators in developing countries have really only been in evidence in any significant way in the last decade (Scaramuzzi, 2002). Incubator growth in China and Brazil started in the late 1980s to early 1990s.

The purpose of this paper is to describe and compare key elements of the incubation landscape in the United States, China and Brazil to provide an understanding of the similarities and differences in incubation systems across the three countries, as well 
as the opportunities and challenges inherent in the macro-environmental and institutional environments for new business creation. For instance, compared to the United States and Brazil, Chinese incubators tend to be relatively more monolithic in terms of business models, due to their high level of dependence on the government for direction and support. At the macro level incubation, systems in the three countries are compared to discuss institutional/environmental/contextual influences on incubator models. Incubation approaches are then described and compared along key dimensions which include strategic objectives, incubator financing/incubator sponsorship and its impact on strategy, client selection criteria, the incubator's service mix with an emphasis on financial services provided by incubators to client firms and performance criteria used to evaluate incubator success. The role of government and its impact on incubator strategy as well as its role in supporting the environment for new business creation is discussed.

\section{Background}

Incubators in the United States, China and Brazil were selected for this study $(\mathrm{N}=$ 30) and interview and archival data were collected by the author from the incubators through semi-structured interviews over a two year period from 2004 to 2006 . The United States has the oldest and largest incubation system with approximately 1000 incubators, which has evolved into an incubation ecosystem with a plethora of incubator models, ranging from public to private incubators. Interestingly, a majority of U.S. incubators operate as non-profit entities and many are university-affiliated. China and Brazil were chosen for this comparative study because these are fast growing emerging markets with the third and fourth ranking business incubation markets in the world. 
Both China and Brazil have experienced extensive changes in their economic, institutional and financial infrastructures, especially in terms of market development, by opening up to global competition and deregulating their markets to reduce the predominant role of the state. Although China has only promoted the creation of small business through the incubation model since the late 1980s, it is the world's largest emerging market and has had an average growth rate annually of over 10 percent for the last decade (Konana, Doggett \& Balasubramanian, 2005); it is second only to the United States in terms of number of incubators. There are now more than 500 incubators in China with over 600,000 employed by those incubators (Ma, 2004). China has a welldeveloped incubation market space, with the government playing a predominant role in the business of incubation by channeling resources to accord with the government mandate of high technology led economic growth. In China, incubators and incubatees alike depend to a large extent on government funds in an environment marked by a paucity of risk capital.

Currently, with over 400 incubators, the Brazilian incubation market is counted as the fourth largest in the world after the United States, Germany and China. Regional and national incubator networks in Brazil are highly evolved and play a significant role in influencing government policy directed at the growth of business incubators. A multitude of government organizations at the federal, state and local levels are involved in assisting incubation efforts. The business incubation landscape in Brazil is vast, varied and complex with a plethora of incubation models, some of which have evolved in response to unique local needs, such as the need for poverty alleviation. 


\section{Literature Review}

\section{Business Incubators and Services}

The National Business Incubation Association of the United States defines business incubators as entities that "accelerate the successful development of entrepreneurial companies through an array of business support resources and services, developed or orchestrated by incubator management and offered both in the incubator and through its network of contacts” (NBIA 2005). Business incubation is especially important in fostering young firms through their most vulnerable phase (Aernoudt, 2002; Kuratko \& LaFollette, 1986) when early demise is attributed to a lack of funding in a majority of cases.

Business incubators are used as economic development tools by almost all countries. Typically, an incubator provides a safe haven for a firm in its early stages of growth through a mix of tangible and intangible services. At a macro level, incubators seek to promote job creation and economic development by linking talent, technology, capital, and know-how in an effective framework to foster the growth of new businesses (Smilor, Gibson, \& Dietrich 1990). At the firm level, the incubator provides a valueadding support system for leveraging entrepreneurial agency, which typically includes a raft of tangible and intangible services to help the new venture get off the ground. Tangible services include shared, subsidized rental space, and office infrastructure, such as secretarial services and business/office equipment. Value-added services in the form of in-house consulting and access to a network of support businesses specializing in marketing, business planning, legal, accounting, and other services are typically provided as intangible services. Financial services to incubatees in many cases include 
introductions or connections to sources of risk capital for the new venture and in some rare cases, direct investment by the incubator in its more promising incubatees (Chandra, He and Fealey 2007).

\section{Business Incubator Funding Sources}

Business incubators in all three countries were predominantly government funded and supported, with some interesting variations in support in the three countries. In the United States, government grants, university/corporate support along with rental and consulting income constituted primary sources of funds for incubators. Support from the state economic development agencies as well as capital funds from the state's legislative allocation, and competitive and matching grants from the state were primary sources of incubator support in the United States (Knopp 2007). Since a majority of incubators in the United States are run as non-profit entities, they operate under a business model that generates additional revenue from rental income and consulting services. Given the structural barriers in the environment to the creation of private enterprise, coupled with the need to transition effectively to a market system, the Chinese government uses business incubators as policy tools of market creation by offering financial support for them both for construction and operations. The Torch Program, a part of the Ministry of Science and Technology (MoST), was set up by the Chinese government to support the creation and growth of incubators in China in 1990s, has invested heavily in incubators through its line of "construction funds."

Brazilian incubators are generally linked to universities and funded by plural government and non-government sources. Financial support for incubators comes from federal government programs such as the PNI (National Incubation Support Program) 
which is designed to support new incubator creation and the expansion of existing ones. The PNI program is supported by a coalition of government, industry and incubator associations, such as the Brazilian Ministry of Science and Technology, the CNPq (National Council for Scientific and Technological Development) and FINEP (Financing Agency for Projects and Studies), SEBRAE (Brazilian Micro and Small Business Support Service) and ANPROTEC (National Association of Incubators and Science Parks) (Scaramuzzi 2002). A major feature of incubation in Brazil is the degree of private involvement - for instance, the Federation of Industries for the state of Sao Paulo (FIESP) operates a dozen incubators. The largest sponsors of incubators are not-forprofit and for-profit organizations, accounting for $40 \%$ of the total (Lalkaka and Shaffer 1999). The coalition of partners that support incubators is a notable feature of the Brazilian incubation scene.

\section{Business Incubation and Government Involvement}

Though incubator models vary widely around the world, most of them have some degree of government involvement. In the United States, for example, incubators are funded by plural government and non-governmental sources, although many of them may receive a majority of funding from state, local or federal governments. Government grants as well as private foundation/university/corporate support add to the financial infrastructure available for incubators. Tax incentives and low interest loans to local government agencies are forms of federal government support.

In China, the visible hand of government has been ubiquitous in the country's economic and political life over the past half century. Business incubators are no exception. Business incubators in China currently have varying levels of government 
involvement, ranging from full ownership to mixed partnership to minimal involvement, particularly in the southern regions of China, such as Shenzhen and Guangdong (Chandra, He and Fealey, 2007). The government has several lines of dedicated funds to support incubation in the form of "construction" funds for incubators, "seed capital" funds for start-ups and "innovation" funds for small and mid-sized ventures that are in the growth phase of their life cycle. In their nascent stages, business incubators in China were mostly supported by the government with a clear mandate for technological advancement and economic development. The government viewed business incubators as a strategic tool for China's transition to a high technology-driven market economy and hence was willing to invest large amounts of resources into these crucibles of entrepreneurship (Harwitt, 2002). The Ministry of Science and Technology made incubator construction a core part of its $10^{\text {th }}$ Five Year Plan (2001-2005), setting aside 50 million yuan (U. S. \$6 million) in annual funding for incubator construction. As a result, incubators in China tend to be larger in terms of size and incubating capacity (Scaramuzzi 2002).

By contrast, universities played a pivotal role in the creation of incubators in Brazil. Government agencies at the federal level play an important role in supporting incubators but seem to work synergistically with universities, industry and incubator associations. Incubators emerged in Brazil with the end of the military regime in the mid 1980s in a grass roots movement that included individuals from several sectors of society, particularly from the university. During the military era, innovation happened by central government mandate, which directed resources to selected industries related to national security. At this time, the private sector primarily sought technologies from foreign 
sources in lieu of homegrown R\&D (Coutinho and Ferraz 1995). Import substitution and technological self-sufficiency were the norm in the military government’s Science \& Technology policy in the context of a hierarchical, centrally planned system. By 1986, the National Research Council (CNPq) had created five technology parks and two incubators, one in Sao Paulo with the state government and one with the Federal University of Santa Catarina (Hoeser 2003). After the fall of the military regime in the mid 1980s, the nexus of innovation shifted from a top-down approach to a bottom-up grass roots approach, with the incubator playing a key role in facilitating new venture creation at a local or regional level (Etzkovitz et al 2005).

The Brazilian incubator movement did not start as a top down process driven by government mandate as in China; it was very much a bottom-up product of multi polar initiatives by key individuals in academia, industry and government. At a macro level, interaction and synergies amongst university-industry-government helped catalyze the growth of incubators. The three stakeholders have worked synergistically to grow this movement amidst a challenging economic and political environment. Today, the incubator is viewed as a hybrid organization that facilitates interaction between the triple helix of university-industry-government spheres (Almeida 2005).

\section{Methodology}

In this study of U.S., Chinese and Brazilian business incubators, a total of 30 incubators were studied. The United States sample included 6 incubators in 6 cities located in Indiana, Maryland, Georgia, Florida and Ohio. The Chinese sample included 12 incubators in 8 cities. A random sample was selected from the key cities in China from Guangzhou and Shenzhen in the South to Shenyang and Dalian in the North, and 
Xian in the West to Shanghai and Tianjin in the East. During June-August of 2004, interviews were conducted with one incubator in each of the seven cities and five in Beijing, the capital of China. Beijing is home to a greater number and variety of incubators than any other city in the country, due to its leading role in China's economic development and industrial innovation. The Brazilian sample consisted of 12 interviews in 4 cities. A sample from Brasilia, the capital of Brazil, Rio de Janeiro, Belo Horizonte in the state of Minas Gerais and Sao Paulo in the south were selected. Interviews were conducted with incubator managers, incubator clients, government officials, trade association representatives and academics in July - August 2006. Sao Paulo has a higher density of incubators and Rio de Janeiro has the broadest scope in incubation models; both cities were well represented in the selected sample.

The interview instrument for the semi-structured, in-depth interviews was developed after a thorough literature review and revised after pilot interviews with incubators in the United States. The pilot interviews served as a pre-test for instrument validation and changes were made to the interview instrument based on the findings and comments. Six incubators in the United States were interviewed to serve as a baseline for the comparison. The instrument was pre-tested and adapted to the Chinese environment by scholars and consultants with extensive experience in China and other Asian markets. The instrument was first translated and back translated from English into Chinese and vice versa by a Chinese-speaking research assistant and then proofread and modified by another Chinese speaker from an academic environment to ensure the accuracy of translation. The semi-structured interview format was selected, since this modality 
provides for focused and systematic information collection, while allowing the interviewee to provide relevant contextual information appropriate to each case.

For each incubator visited, the president, vice president, or director/manager in charge of corporate affairs was interviewed. In addition, the sample included visits with incubator association directors, academics and entrepreneurs located in the incubators. They were selected as key informants, since they were in the best position to provide an overview of the incubator's strategic direction, as well as its history and background. In China, the interviewees were native Chinese speakers who did not speak English. They were provided a copy of the instrument in Chinese either prior to the interview by e-mail, or handed a copy of the interview instrument at the beginning of the interview in Chinese. The same interview protocol was followed in Brazil, where most of the interviewees spoke English, with one exception where a translator was used. All interviews were

recorded with the interviewee's permission and transcribed for analysis. On average each interview lasted for 1 hour and 35 minutes/hours.

\section{Results}

From the literature review and analysis of the interview data, four key environmental and incubator-level dimensions emerged: institutional environment for new venture creation, role of government in incubator development, incubator financial model, and the incubator service mix, including financial services provided to client firms. In the first part of the following section, generic types of incubator models in the three countries are described. This is followed by a description of some of the indigenous models unique to China and Brazil. These models are unique in the sense that they have evolved in response to local conditions in each country. The incubation approaches are 
then compared and contrasted along the key dimensions identified from the interview data to provide an overview and critical assessment of the state of business incubation in the three countries. Conclusions and policy implications are addressed in the last section.

\section{Generic Models of Business Incubators}

Business incubator models in all three countries are driven, in large measure, by the type of tenant business and the agendas of the primary sponsors. Both China and Brazil have been evolving indigenous models of incubation after more than a decade of growth. The generic models found in all three countries are presented first followed by the unique models in Brazil and in China.

1. Technology incubators - In the United States, high technology incubators generally have a university affiliation along with a focus on a specialized technology that coincides with the area of expertise at the university. This category represents the first generation of incubators in China. These incubators focus on a variety of high technology fields, such as new materials, environmental technologies, etc. They provide space and general services to start-ups, which originate from universities, research institutes and stateowned enterprises. In Brazil, technology focused incubators were primarily associated with and supported by the universities, federal/state governments and related industries, with students and professors as key founders of businesses.

2. Specialized high-tech incubator - In the United States, this category of incubators focuses on a certain aspect of high-technology to capitalize on proximity to university resources or to other sources of funding. The Chesapeake Innovation Center (CIC) is located close to the federal government and capitalizes on its locational advantage by incubating businesses/technologies related to homeland defense and security. 
In China and Brazil, this class of incubator focuses on a specific field of hightechnology, such as software or biomedicine and provides specialized services to incubatees in these areas. This category of incubators has witnessed rapid growth in the past decade and comprises about $10 \%$ of incubators in China. In Brazil, the focused high technology incubators are affiliated with specific industry clusters as well as corporations that support their development. Good examples are Biominas and FUMSOFT, associated with the biotechnology and software clusters respectively.

3. University-based incubator - This category is very popular in the United States. These incubators are housed in universities and supported by their parent universities, as well as with government and private funds, in some cases. Technology transfer and commercialization are the twin goals of the university incubator that offers multiple spillover benefits to the university and to the larger community. In China, the primary focus of this type of incubator is to promote commercialization of university research by taking advantage of preferential governmental policies, as well as the intellectual and informational resources of the university. In Brazil, most incubators have a university affiliation. The goals of the university-based incubator are very similar to those in the United States and China. Universities in Brazil appear to work more synergistically with industry and private associations compared to the United States and China.

4. Traditional/Community-based incubators - In the United States, these incubators are supported by state and local economic development agencies, as well as by local chambers of commerce with a view to economic development of the area. In China, traditional incubators that took in a variety of incubatees in unrelated industries was 
relatively rare, due to the government's policy of creating and supporting the growth of high technology-driven economic growth through the incubator mechanism.

In Brazil, traditional incubators were created in response to the social problems of unemployment with the goal of regional/local development. The private sector/industry associations along with various levels of government, acted in concert to create new firms in industrial sectors traditional to that particular region, such as shoes, furniture, fashion or agricultural equipment. Financing of these incubators came largely from institutions such as FIESP (Federation of Industries of the state of Sao Paulo), SEBRAE (Brazilian Micro and Small Business Support Service) and the municipal governments (ANPROTEC Database).

5. Private/Corporate incubator - In the United States, companies, such as Motorola, have their own in-house incubators to grow businesses related to their specific technology needs. These incubators are funded by their parent corporations or by venture capitalists. In China, privately supported incubators are still rare, except in the South where there are nascent experiments with public-private partnerships in incubator founding and support. Some of these incubators are starting to invest their own risk capital in their more promising clients. In Brazil, most private incubators concentrated in the area of information technology appeared in 1999. Funded primarily by venture capitalists and by information technology professionals, the hallmark of these private incubators was the investment of capital in their promising client firms along with business development services provided by the founding partners. As in the United States, this type of incubator in Brazil is also housed in the context of a large company that aims to foster new ventures selectively in order to reap the benefits of innovation. The Brazilian oil 
giant Petrobras has a good example of this type of incubator with close ties to the Federal University of Rio de Janeiro. Company incubators have witnessed remarkable growth in the last few years (Kantis 2005).

\section{Indigenous Incubation Models:}

China - China has a rather single-minded focus on high technology; hence its incubation models have a monolithic pattern. The variations were the State Owned Enterprise (SOE) incubator and the returned Chinese student incubator. The first was a result of historical and political circumstances; the second a response to the large number of overseas Chinese students returning home to start ventures in a newly open environment.

Innovation Park for Returned Scholars - This particular category of incubators was set up to attract overseas talent - scholars and students - from the Chinese diaspora to set up high-tech businesses in China. Generous subsidies, the form of low cost space usually at universities and other forms of assistance, are used to attract homeward bound talent.

State Owned Enterprise incubator - The SOE incubator bears some similarity to the corporate incubator; however this type of incubator is housed in and supported by the parent SOE with the intent of creating new technologies for the benefit of the parent SOE and for absorbing redundant workers from the parent company. They suffer from lack of strong managerial talent, since they are staffed by managers with little market experience.

Brazil - Brazilian incubators exhibit the broadest scope of incubation models in comparison with other countries, such as China, where incubator models tend to be more monolithic and technology-focused. The Brazilian incubation environment offers a 
plurality of approaches and configurations of incubation ranging from the traditional, design, cultural, social, and high-technology oriented incubators, with indigenous models, such as the "social" incubator that is unique to Brazil. The incubation approaches are a blend of global and local models that have evolved in response to local needs, i.e., particularly the need to alleviate poverty and create jobs for the economically disadvantaged.

Cooperative/ Social Incubator - Social problems related to unemployment in the Brazilian economy were exacerbated by the opening up of the economy to foreign competition after 1990. A series of initiatives by universities and concerned citizens attempted to combat poverty and related ills by transferring the incubator model to the social sphere in order to create jobs and growth. Funding for these incubators came from the university and state and municipal governments interested in economic development at the local and regional levels, with the university serving as the primary source of knowledge and training to the cooperatives (Almeida 2005). Due to historically weak economic conditions, Brazil has a relatively high degree of "necessity” entrepreneurs compared to "opportunity" entrepreneurs. Social or cooperative incubators are designed to help these necessity entrepreneurs take their idea to market. While technological entrepreneurs take advantage of opportunity, the social entrepreneurs do it out of necessity. Social incubators try to create an entrepreneurial environment in the community, through workshops and individualized assistance in design, production and marketing (Interviews in Rio de Janeiro and Brasilia 2006).

Cultural Incubator - This type of incubator is aimed at fostering entrepreneurship in the field of culture, i.e. music, arts, sculpture, photography and cinema, among others 
(Scaramuzzi 2002). Cultural incubators are unique to Brazil: incubators at University of Brasilia and one of the Genesis incubators in Rio de Janeiro represent strong examples of this genre of incubator. Support for cultural incubators come from affiliated universities as well as the state and federal governments that have an interest in sponsoring local art and culture. A cultural incubator manager pointed out that the entrepreneur in this area has a unique profile and is in business for love rather than money, hence needing very specialized assistance (Rio de Janeiro Interview 2006).

\section{Institutional Environment for New Venture Creation}

The institutional structure and maturity of its institutions in a country shapes the environment for incubation, and this holds true in the United States, China and Brazil. Availability of capital as well as the structure of financial markets is a key determinant of growth of fledgling ventures (Bhide, 2000). Banking reform in China has been slow and halting, as witnessed by the fact that the government-owned Big Four banks still control about $55 \%$ of the country's banking assets. Banks are the lenders of last resort for incubators in an environment marked by a fledgling stock market and lack of many other funding alternatives (Guerrera, 2005). At the macro-level, new business creation in a market environment, such as the United States, is facilitated by the presence of wellestablished institutions of capitalism, such as an independent and solvent banking system, a deep stock market, clear property rights, a legal system to guarantee such rights, etc. These institutions serve to reduce friction by lowering transaction costs of doing business. Weak institutional structures could result in market failures, or "gaps" in the system that hinder new business creation. China and to some extent Brazil are both in the process of developing or strengthening these institutions that provide the framework for a 
market economy; hence market failure is a bigger issue in these countries. The government uses business incubators as a tool to address some of these instances of market failure and to provide a safe haven to new businesses. In China, business incubators are a policy tool and instrument of choice for government-mandated, high tech-driven economic development and have accordingly received vast inputs of physical and financial resources from the government. The incubation environment in China is rich in physical resources but needs to address the issue of deepening its management capability. A government-dominated banking sector that is averse to making small loans to undercapitalized new businesses is another hindrance for new ventures wishing to obtain risk capital. Interviewees in China indicated that people in China overwhelmingly prefer the safety of bank deposits over riskier investments in stocks. A risk averse culture coupled with shallow capital markets and lower levels of acceptance of entrepreneurship as a means of wealth creation translates into few angel investors or other forms of risk capital.

Whereas interviewees in both China and Brazil noted that lack of risk capital and government interference were key barriers to new venture creation, the Brazilian interviewees additionally noted bureaucratic and regulatory burdens as key barriers to new businesses. The GEM (Global Entrepreneurship Monitor) Report on Brazil indicates that the main obstacles to business are capital scarcity and high cost, bureaucratic interference in the form of heavy taxes and regulatory burden, lack of coordinated and easily accessible information on entrepreneurial support systems/programs, and an educational system that does not foster an entrepreneurial spirit. Unlike the culture in the United States, which tends to encourage entrepreneurial risk taking, Brazilian culture 
tends to be risk averse, encouraging people to prefer the security of a formal job with a large company over an entrepreneurial career fraught with risk and uncertain outcomes (GEM 2003, Sao Paulo Interview).

Many interviewees indicated that heavy bureaucracy and red tape were key reasons why many Brazilian entrepreneurs opt to remain in the informal economy. Incorporating a start up requires 15 procedures, three times more than in the United States. New companies must register with the appropriate government agency, apply for licenses and permits from several state and federal departments, such as environment and labor, register for taxes at multiple levels of government and provide evidence of membership in relevant trade organizations, all of which can easily take more than 5 months (National Dialogue on Entrepreneurship 2005). Capital scarcity and lack of awareness of the incubator as a support mechanism were cited by others as hindering new business creation. Lack of private investment and high dependence on government for survival, along with the lack of a well-developed venture capital (VC) market for risk capital in the later stages of a new firm's growth were cited as major barriers to growth. The world of incubation is not well-known in Brazil, even with nearly 400 incubators in existence, and the venture capital market is still in its infancy (Sao Paulo Interview).

The interviews in the United States, China and Brazil indicated that incubator strategies are driven by contextual features of the incubation landscape in a country. In China, incubators were viewed as a public good entity with a social mission and tended to operate under a government mandate of economic development. In Brazil, there was a general lack of awareness of the world of incubation, in spite of the country's 400 incubators, whose primary goal was to foster a culture of entrepreneurship and to 
promote economic development. In the United States, the focus of incubation was on nurturing entrepreneurs with the goals of economic profitability, technology transfer, commercialization and job creation. However, these strategic objectives tended to vary with the business model of the incubator and type of sponsorship/level of government involvement.

\section{Government Involvement in Incubators}

Role of Government - United States - In the United States, government involvement is manifested through funding from federal, state and local levels; however, a greater diversity of incubator models has resulted in plural approaches to funding. State governments play a predominant role in supporting incubators in the United States, with legislative allocations for economic development going to support incubators in many of the states, and with the local and federal levels of government playing a supportive role in incubator sponsorship. The source of incubator funding in many instances determines the incubators' strategic focus and tenant selection. For instance, government-funded incubators operate with a goal of economic development, relative to a universityaffiliated incubator that may have technology transfer as its primary goal.

Role of Government - China - In China, government involvement in incubator founding and operations is typically quite high, with the government impacting incubator models, organization, funding and strategy for the incubator (Scaramuzzi 2002). The interviewees in China spoke with one voice in affirming the importance of government support for incubation. The government heavily subsidizes incubator construction as well as ongoing incubator operations and is involved in operational decisions of the incubator. In general, incubators that are funded and supported financially by the government tend to have 
different operational features from incubators that are primarily supported by diverse partners such as universities and private entities. In a majority of the Chinese incubators, the government was the primary source of funds for establishing incubators with the implicit understanding that the incubator would become financially independent in due course. Even though incubators are required by the Chinese government to reach selfsustainability in three years, many of the incubators interviewed had not reached that goal and were still heavily dependent on ongoing subsidies from the government to support operations. Rental incomes from client firms constituted a very small portion of the incubators' revenues and were not significant enough to cover operational costs.

It was noted in China that government involvement negatively impacted the incubators' market orientation and entrepreneurial proclivity, as well as their financial service intensity. Higher levels of government involvement appeared to correlate with more arm's length financial involvement with incubatees, such as linking them with sources of financial assistance, whereas lower levels of government involvement increased the incubator's entrepreneurial proclivity and led them to make riskier direct investment in their client firms (Chandra and He, 2008). Incubators in the southern regions, such as Shenzhen, tended to have mixed ownership structures (public/ private) and were more likely to make direct investments in incubators. In contrast, the incubators in the north with heavy government involvement tended to maintain an arm's length financial relationship with their incubatees (Chandra, He and Fealey, 2007).

Role of Government - Brazil - The government works in tandem with universities and industry to support business incubation efforts in Brazil. The two major objectives of the government are technology development and social development (ANROTEC Interview 
2006). Universities in Brazil have a strong interest in providing benefits to society and industry has a vested interest in homegrown technologies that would benefit them. All three stakeholders view incubators as a tool that has the potential to advance their objectives. This synchrony of objectives along with strong incubator associations has resulted in several innovative and timely initiatives from different levels of government to facilitate new business creation, such as the new Innovation Law passed in 2005, which legalizes the act of a researcher at a federal university setting up a company in his/her name. The Law clarifies the work relationship between the researcher and the federal government by allowing a researcher to leave the university for a period of time to work for a private company and then return to the university, if she/he desires. The most innovative element of the law is the possibility of using money from the government to support companies. Under the law FINEP, a government agency would be authorized to provide federal grants to companies for specific research. These research grants aimed at fostering innovation is probably the most innovative aspect of the law (Rio de Janeiro, Belo Horizonte, ANPROTEC, Sao Paulo Interviews).

The interaction between the incubators and elements of the triple helix, such as government, university and industry, could be responsible for some of the innovative approaches developed by some incubators to incubating new firms. A technology incubator in Belo Horizonte described their approach as demand-oriented incubation, which is aimed at creating companies based on cluster needs in that particular region, which directs innovation at market needs. Qualified professionals with industry experience are used to conduct a market analysis along with expert panels that identify products based on the market analysis of industry need (Belo Horizonte Interview 2006). 


\section{Incubator Financial Sponsorship Model}

Incubator Financial Sponsorship - United States - The United States has a greater diversity of incubation models, along with an attendant diversity of funding sources for these incubators. While many incubators in the United States are government funded, through federal, state and local level sources, county grants and corporate sources add to the range of funding for incubators. In addition to rental income and service fees, some incubators generate revenue by cashing in on their equity positions in their successful incubatees. University affiliated incubators in the United States are largely funded by their parent universities with additional support from government/private grants. Other sources of funds for incubators are federal agencies, such as the U. S. Department of Commerce, state and local economic development agencies interested in job creation, local banks interested in creating a potential business relationship with incubator clients, the local Chamber of Commerce, and corporate and community foundations.

Several types of formal and informal support are available to incubators in the United States. Formal support includes capital funds from the state’s legislative allocation for incubator infrastructure, competitive grants from the state to select incubators, matching grants for service support for new ventures and funds that are channeled through the state economic development agency. Informal sources of support include tax incentives in the form of tax credits to businesses investing in incubators, low interest loans to local government agencies to support investment in incubators, and private partnership funding, wherein incubators raise money from a coalition of businesses and banks for operational funds. In addition, a few incubators have seed fund programs that invest in new ventures in the early stages (Knopp 2007). 
Incubator Financial Sponsorship - China - Lalkaka, Feng-Ling \& Lalkaka (2000) provide a typology of sponsors for Torch incubators in China. They include, in order of importance, Provincial/ Municipal Science and Technology Commissions (STC), High Tech Enterprise Zones, Jointly by STC and Tech Zone, State-Owned Enterprises, Universities, Economic Zones, and Jointly by University and Economic Zone. In general, incubators in China are fully sponsored and funded by the government, university sponsored, state-owned enterprise sponsored or public/private sponsored.

A majority of incubators in China are sponsored by the Ministry of Science and Technology's (MOST) Torch Program, which is a government program focused on developing and promoting the commercialization, industrialization and internationalization of high technology research in the country (Torch Center 2003). The Torch Program has several lines of funding for incubators and incubatees. The Construction Fund from the Torch Program, along with financial support from the local governments, forms the mainstay for incubator funding. Science and Technology (S\&T) Commissions at local levels are in charge of organizing, developing and financing high tech innovation centers at the local level. Construction funds from the central government are earmarked for buildings/facilities, salaries and office expenses. A part of the construction funds is used to assist incubatees with business development expenses. Hence, the government covers the initial cost of investment, as well as a large part of the operational cost of these high tech innovation centers/business incubators.

Thus, incubator sponsorship in China tended to be more monochromatic, with the government playing a very big role relative to the United States, which has a much 
greater range in incubator sponsorship, resulting in greater variety in sources of funds compared to China.

Incubator Financial Sponsorship - Brazil - Incubators in Brazil are generally funded by a coalition of partners from the public and private sectors. A representative example is the CIETEC incubator created in 1998 and housed in the University of Sao Paulo, Sao Paulo. CIETEC, a technology-based incubator center, was created as a partnership between the MCT (Ministry of Science and Technology), SCTDE (Science, Technology and Economic Development Secretary of the state of Sao Paulo), USP (University of Sao Paulo), IPEN( Nuclear and Energy Research Institute), IPT (Institute of Technological Research) and SEBRAE (Brazilian Micro and Small Business Support Service) along with support from CNPq (National Council for Scientific and Technological Development), FAPESP (Research Support Foundation of the state of Sao Paulo) and FINEP (Financing Agency for Projects and Studies) (Interview and archival data, August 2006).

FINEP (Financing Agency for Projects and Studies), a division of the Ministry of Science and Technology has a program, the PNI to support Brazilian national incubation. It is linked to the Ministry of Science and Technology and is instrumental in formulating policy for business incubators (ANPROTEC Interview, Brasilia, 2006). FINEP recently issued a call for proposals from larger "anchor” incubators to help smaller incubators. The proposal from the anchor incubator would have to include a plan for helping at least three smaller incubators (Interviews in Sao Paulo, Rio de Janeiro 2006). These calls are instrumental in selecting strong incubators with innovative ideas to work in partnership 
with smaller, resource-constrained incubators in the region while providing learning, networking and knowledge transfer opportunities.

SEBRAE (Brazilian Micro and Small Business Support Service) is a non-profit public-private entity that supports incubator and small business development by utilizing a mix of funds from government payroll taxes and private sources. With 27 branches in Brazil, SEBRAE has invested around \$50 million to stimulate creation, development and consolidation of incubators. Initially, SEBRAE has provided infrastructure funding for many incubators in the first round and is now focused more on providing start up funding and training to new ventures (SEBRAE Interview, Brasilia 2006). The dynamic and context sensitive nature of SEBRAE funding is evident from the fact that this organization is constantly reinventing its funding focus, as appropriate to the evolving nature of incubation. One incubator manager pointed out that, at present SEBRAE's focus is on the development of productive industry clusters. Incubators receive funds on a competitive basis for cluster development and are able to indirectly support new businesses in the cluster with these funds (Belo Horizonte, 2006).

Brazilian incubators receive support from a broad spectrum of federal agencies, such as FINEP, public-private entities like SEBRAE, strong national incubator associations, such as ANPROTEC as well as local, state and city governments. Corporations such as Petrobras and Biobras support focused incubators related to their technology cluster. The interaction between government, universities and industry appears to be synergistic and relatively well-coordinated, with incubator industry associations playing a boundary spanning role. 


\section{Incubator Services/Financial Services}

A new venture's capital needs vary over its life cycle from inception through its growth stages. Most countries have gaps in the capital market for early stage funding when firms have little or no track record and/or collateral to seek funding from banks. Lack of financing for new ventures will thwart the creation of dynamic local economies built around a robust SME sector. Access to financing is crucial factor for innovation to occur (Mytelka and Farinelli 2003). Gaps in financing, particularly for early stage ventures, can be a major deterrent to new business creation, often leading to a fledgling venture's early demise. Financial institutions are hesitant to lend money to a firm with little or no track record and no collateral. Even in a developed market economy, such as the United States, there are some gaps in the financing chain for new ventures. For example, a start up at the earliest stages of its creation is often dependent on personal funds and funds from friends/family for the most part. Figure 1 provides an overview of a typical financing chain for a new venture over its life cycle with its changing capital needs. 
Figure 1

Financing Chain for a New Venture

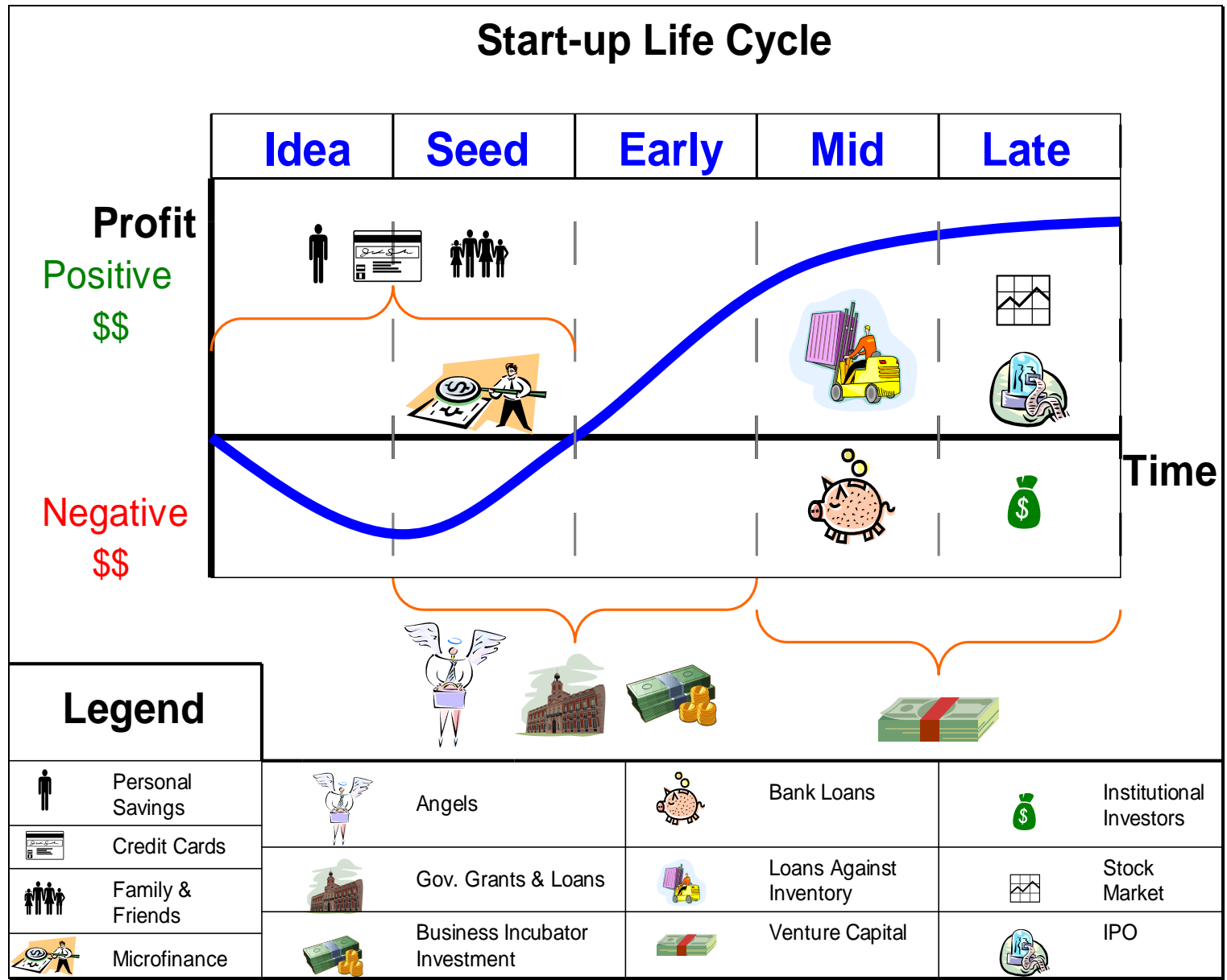

Incubators provide administrative/managerial as well as financial service support to incubatees, whose financial needs evolve in tune with their life cycle as they move from concept to seed to early, mid and late stage growth (Zedvitz 2003). Gaps in the financing chain are most obvious in the early stages of the start up.

Incubator services to incubatees can be broadly categorized into:

1. Basic/administrative services, such as rental space and secretarial assistance

2. Financial services 


\section{Consulting/Training services}

\section{Networking}

United States - Services - The service mix in United States incubators varies with the strategic agenda of the sponsor's motives and the type of incubator model. Communitybased incubators are more likely to offer basic, tangible services, since their tenant mix generally consists of a range of businesses from various industries. University-affiliated incubators are focused on technology transfer and commercialization and tend to draw upon the resources and networks of the parent university to assist incubated firms. Since faculty is a rich source of expertise, these incubators tend to emphasize the consulting and networking dimension to a larger extent. Corporate incubators typically grow firms related to the parent firms' technology and provide targeted assistance to the firms housed in their incubator. Specialized incubators draw upon their locational or specific resource advantage to help incubatee firms in specific areas related to their advantages. For example, ATDC Savannah incubates firms in the area of maritime logistics to capitalize on their proximity to the port of Savannah and the Maritime Logistics Center. In general, incubators in the United States are moving toward a service mix that emphasizes higher, value-added services such as networking, which is now recognized as more valuable in the service continuum of incubators (Ekholm and Haapasalo 2002). United States - Financial Services - Incubators in the United States provide a range of financial services to the incubatees, including assistance in securing grants from various government agencies at the federal, state and local levels. The Small Business Innovation Research grants and the Small Business Administration grants and loans are popular forms of assistance for certain types of businesses. During the early growth stage, 
bank loans are an option for a financially viable business. To secure bank loans, a strong business plan that includes credible financial projections is a necessary part of the process. In most cases, United States incubators provide assistance in business plan development. A network of relationships, built by the incubator with banks and other service providers, also helps facilitate access to funding from banks for the venture by providing some added credibility. Angel investors may step in at this point to fill the gap, in some cases, in the United States. In the later stages of the venture's life cycle, the incubator may use the power of its network to connect the venture with venture capitalists. Once the growing venture has reached profitable maturity, it has several exit options, such as an IPO or acquisition. Even with fewer gaps in the financing chain in the United States, new venture failure is quite high, partly due to financing gaps in the seed to early stages when the new venture is most vulnerable. A few incubators in the United States have seed funds that invest directly in their incubated firms with the expectation of realizing gains upon the success of the incubated firm; however this type of direct financial participation is relatively uncommon. China, on the other hand, lacks the range and depth of financial services as compared to the United States.

China - Services - Incubators in the United States and China provide a varying mix of tangible and intangible services. For instance, incubators in China tend to focus on the basic services, which are tangible in nature ranging from office space/equipment/labs to conference rooms, as well as some consulting advice. The latter mostly comes in the form of providing assistance to incubatees on ways to access government grants and to navigate government bureaucracy. Networking assistance is provided to help connect firms to banks and other forms of financial assistance. Networking by Chinese incubators 
is functional in nature and is meant to connect the new venture to banks and sources of government monies. However, the emphasis is clearly on tangible services. Incubators in China are housed in huge, imposing special purpose buildings constructed with government construction funds from the Torch Program.

China - Financial Services - While early stage financing gaps are problematic in most countries, the result could be devastating to new business creation in a country such as China that is lacking a fully-developed market system. Business incubators in China have a variety of strategies such as helping incubatees access government grants and "seed funds" in the early stages of the new ventures' life cycle, and from banks, and in rare cases, from angel investors and venture capitalists at later stages. Other types of financial services come in the form of low interest loans and loan guarantees. In addition, some incubators make direct investments in the incubated firms along with providing soft loans for use as circulating capital. Incubators in China facilitate access to these government funds by their client firms as part of their services. Incubators, in turn, are funded largely by the government and are dependent on the government for operational funds. In China, shallow capital markets, difficulty in accessing capital from banks, and a paucity of angels/venture capital add to the inhospitable environment for start-ups at the later stages of growth when its capital needs go up exponentially and limit exit options for new ventures. In the United States, it is not uncommon for a successful new venture to be acquired by a large firm or go to the capital market for additional funds through an IPO. In China, acquisitions by larger firms are also relatively rare in this environment, where market creation is still in its nascent stages. Given China's shallow capital markets, exit options for the incubatees are rather limited. In addition, in the United 
States, the venture capital option is also available to a few high potential firms in certain areas. Private involvement in incubation is still not common in China, except in the South where mixed partnerships for incubation are gaining ground. In the United States, by contrast, there is a greater range and variety of incubator models, some of them funded by corporations or private entities, such as venture capitalists. Government-sponsored incubators in China enjoy preferential tax policies, and in some cases, their incubatees enjoy tax breaks as well. Most of the start-up capital available to new ventures is provided by the government (Lalkaka, 2003; Chen, Yin, \& Zhu, 2003) in the form of grants or soft loans.

Brazil - Services - The Brazilian incubator movement is defined by its provision of unique and specialized services to support new businesses by providing an innovative environment for their growth through guidance and consulting, in addition to physical space and operational infrastructure (CIETEC Report 2003/2004). Particular services provided include traditional services, i.e. physical services, access to university labs and infrastructure, and training courses sponsored by SEBRAE. Higher value services include technology breakfast networking focused on different areas, i.e. biotech focus. The breakfast meetings would include several actors involved in the biotech arena. Informal cluster networking amongst client firms is also a part of incubator's services. CIETEC has access to media where the incubator manager talks about CIETEC projects on a radio program (CIETEC, Sao Paulo Interview 2006).

Brazil - Financial Services - In the early stages of a new venture's life cycle, bank loans are difficult to secure due to lack of collateral, high interest rates, and a general distrust of the banking system by Brazilian entrepreneurs (Rio de Janeiro, Sao Paulo, Belo Horionte 
Interviews 2006). The government does not invest money directly into small businesses in Brazil (ANPROTEC Interview). The federal agency, FINEP provides money for projects done in conjunction with a university or research institute. Because Brazilian law does not allow direct flow of government funds to a company, the money goes to the university to finance a project within the company (Belo Horizonte Interview). FINEP addressed the need for financing at various stages of firm growth from inception with a $0 \%$ interest program to stimulate firm growth in early stages. It has a venture capital program called INOVAR, as well as a seed capital program that provides funding for early stage growth. BNDES (Bank for Social Development), which used to support only big companies, now has a support program for microenterprises. Bank loans are not a feasible alternative for small companies in Brazil, since interest rates are very high and it is difficult for microenterprises to borrow money without collateral (ANPROTEC Interview, Brasilia 2006).

It is relatively rare for an incubator to invest its own money in one of its client firms, though some incubators are experimenting with this approach. One incubator manager discussed their intent of moving from a service model where the incubator offered services, infrastructure and management services in return for rental fee to a "partnership" model where the incubator takes a financial stake in the firm in lieu of rent and the payoff for the incubator comes in the form of profit sharing (Belo Horizonte Interview) Another incubator manager in Rio de Janeiro pointed out that they currently do not invest in their incubatees, but are discussing the possibility of being a member of a seed money fund that would be funded by a coalition of public and private partners (Rio 
de Janeiro Interview 2006). Currently, most Brazilian incubators, as in China follow a more conservative model of linking client firms to potential investors.

A biotech focused incubator in Belo Horizonte has started an innovative program with the Inter American Bank (IAB) to finance new companies in Brazil. IAB gives the incubator grant money of $\$ 200,000$ - \$1 million to invest in promising new firms. The recipient has to match the money dollar for dollar. The program allows the incubator to invest money in the company and the return on investment is then reinvested in other companies. This particular incubator had financed 12 companies through the IAB Program. This incubator has also started a seed capital program in partnership with FINEP and FAPEMIG (State Agency for Science and Technology) of \$10 million reais to invest as seed capital in early stage biotech ventures, with the incubator taking a 2530\% stake in the venture in return for its investment (Belo Horizonte Interview 2006).

The INOVAR Project led by FINEP is a consortium of local and foreign VC firms for establishing an institutional structure for promoting the capacity and culture of venture capital. The goal is to set up a \$200 million fund for tech based ventures, a web site for information and virtual matchmaking, a Venture Forum and network to support high potential entrepreneurs (Lalkaka 2003). In general, interviewees pointed out that there was a mix of state, federal, some private funds/venture capital and some seed money, but there clearly are gaps in the financing chain that need to be addressed.

\section{Conclusions and Policy Implications}

Incubation approaches in developed and developing countries bear many similarities; however, at the macro level incubation is very much influenced by the nature of the institutional and cultural context. At the incubator level, the strategic focus of the 
incubator along with its service mix are impacted by the nature of its client base as well as the resources available to the incubator in its immediate environment. This study has focused to a large measure on the nature of incubator financing and the financial services it in turn offers its incubatee clients, both of which are very much dependent on political, economic and institutional factors in each country context. For instance, in both China and in Brazil, financial institutions have not fully addressed the risk capital needs of early stage ventures; hence in both instances the government has stepped in to fill the gaps in the financing chain by setting up various lines of seed capital funds separately and in conjunction with business incubators. Incubators in all three countries facilitate access to a range of financial services to their incubatees by serving as an intermediary, but very few have the resources to make direct investments in their incubatee firms. This may indicate that in the early stages governments may need to address market failure by stepping in with some form of support for early stage start-ups, since most countries have a paucity of risk capital for early stage firms.

The downside of this approach is a high level of dependence on government, which is a hallmark of incubators across countries. The irony of incubation is that incubators are set up as intervention tools to address market failure, such as gaps in financing for new ventures in many cases, yet many of them are run as non-profits and have trouble meeting self-sustainability goals in almost all country contexts. Chinese incubators have a singular focus on high technology based incubatees, are heavily dependent primarily on government funding and do not have the range of incubation models seen in Brazil. By contrast, Brazilian incubators have a range of funding sources from different levels of government and a mix of public-private support, and strong 
networks amongst the triple helix worked in their favor in terms of gaining policy support from government. Policy implications of this finding at the incubator level are that incubators may need to consider gaining support from plural sources, both government and private, in order to reduce excessive dependence on any one source and may also need to have clearly articulated performance criteria in order to be exposed to the full effects of the market in the same way as the new ventures they foster.

Figure 2 summarizes the key differences between incubation approaches in the United States, China and Brazil. The strategic foci of incubators in the United States is more on technology transfer/commercialization and economic development, whereas Chinese incubators have a clear social mission mandated to them by the government. In Brazil, incubators work under a Darwinian system with a range of government programs designed to promote competition and support the fittest through awards to incubators with the most innovative proposals. As a result, incubators in Brazil need to earn government monies rather than receive it as a matter of fact.

There is general recognition in recent incubation literature (Hansen et all 2000; Grandi and Grimaldi 2004; Ekholm and Haapasalo 2002) that incubators are emphasizing softer, intangible services such as networking. Here the Chinese and Brazilian approaches offer a stark contrast. Chinese incubators are driven largely by government fiat and tend to be housed in large buildings, with space for an average of 100-150 incubatees, whereas their Brazilian counterparts are smaller, averaging 15 - 20 incubatees with emphasis placed on softer services, such as networking and training. Many of the Chinese incubators are staffed by former SOE managers; hence management capability to nurture new firms in a free market environment is not very strong, compared 
to the United States or even Brazil, where managers tended to have relatively more market experience.

Indigenous models of incubation, such as the social incubator and the returned scholar incubator have evolved in countries such as Brazil and China in response to local needs. These models are innovative adaptations of global models of incubation and are noteworthy in their attempt to localize incubation efforts. Successful incubation requires adaptation of global models to local needs, as well as the creation of an entire incubation ecosystem that encompasses networks linking government, businesses, universities, trade associations, entrepreneurs, service providers and financial institutions that can meet the needs of a new venture's capital requirements.

The United States, Chinese and Brazilian experiments with incubation to stimulate economic growth in targeted sectors, i.e., high-technology, biotechnology or the environment, have implications for incubation practices on a global scale. Some of the key findings of the proposed study would have applicability to other nations across the globe seeking economic development objectives at a macro level coupled with new business creation at a micro level. This paper draws attention to the varying modalities of incubation approaches in the United States, China and Brazil, with special emphasis on organic/indigenous models, as compared to key global markets. Hence, a study of incubation and the innovation ecosystem in these leading incubation markets will have relevance not just in cross cultural comparative settings, but also to global incubation in developed and developing countries, both in terms of policy and practice. 
Figure 2

Comparison of Incubation Models in the United States, China and Brazil

\begin{tabular}{|c|c|c|c|}
\hline & USA & CHINA & BRAZIL \\
\hline Strategic Focus & $\begin{array}{l}\text { Economic } \\
\text { development, tech } \\
\text { transfer and } \\
\text { commercialization. }\end{array}$ & $\begin{array}{l}\text { Social mission, } \\
\text { economic } \\
\text { development with } \\
\text { high tech focus. }\end{array}$ & $\begin{array}{l}\text { Foster } \\
\text { entrepreneurship, } \\
\text { economic } \\
\text { development, job } \\
\text { creation, technology } \\
\text { commercialization. }\end{array}$ \\
\hline $\begin{array}{l}\text { Sponsorship/ } \\
\text { Incubator } \\
\text { Funding }\end{array}$ & $\begin{array}{l}\text { Multiple levels of } \\
\text { govt., economic } \\
\text { development } \\
\text { organizations, private } \\
\text { funding }\end{array}$ & $\begin{array}{l}\text { Govt. is } \\
\text { predominant } \\
\text { funding source for } \\
\text { incubators and } \\
\text { incubatees }\end{array}$ & $\begin{array}{l}\text { Plural sources of } \\
\text { funding include } \\
\text { different levels of } \\
\text { govt., universities and } \\
\text { some private funds }\end{array}$ \\
\hline $\begin{array}{l}\text { Type of } \\
\text { Incubatee } \\
\text { Business }\end{array}$ & $\begin{array}{l}\text { Mixed, high-tech, } \\
\text { specialized. }\end{array}$ & $\begin{array}{l}\text { Mostly high tech } \\
\text { (software, } \\
\text { hardware, biotech } \\
\text { etc). }\end{array}$ & $\begin{array}{l}\text { High-tech, mixed in } \\
\text { social, culture and } \\
\text { design incubators. }\end{array}$ \\
\hline Service Mix & $\begin{array}{l}\text { Tangible and } \\
\text { specialized, value } \\
\text { adding services. }\end{array}$ & $\begin{array}{l}\text { Mostly tangible } \\
\text { services of an } \\
\text { administrative } \\
\text { nature. }\end{array}$ & $\begin{array}{l}\text { Both hard and soft } \\
\text { services, such as } \\
\text { networking. }\end{array}$ \\
\hline $\begin{array}{l}\text { Financial } \\
\text { Services }\end{array}$ & $\begin{array}{l}\text { Provides links to } \\
\text { sources of financing } \\
\text { with a few investing } \\
\text { directly in incubates. }\end{array}$ & $\begin{array}{l}\text { Links to various } \\
\text { sources of govt. } \\
\text { grants, bank loans } \\
\text { and some VC } \\
\text { funding. Rare } \\
\text { cases in south of } \\
\text { direct investment } \\
\text { in incubatees. }\end{array}$ & $\begin{array}{l}\text { Links to various } \\
\text { sources of govt. } \\
\text { funding lines, angels } \\
\text { and VCs. Bank loans } \\
\text { difficult to secure for } \\
\text { start-ups. Rare cases } \\
\text { of direct investment in } \\
\text { incubatees. }\end{array}$ \\
\hline $\begin{array}{l}\text { Tenant Entry/ } \\
\text { Exit Criteria }\end{array}$ & $\begin{array}{l}\text { Clearly stated and } \\
\text { adhered to mostly. }\end{array}$ & $\begin{array}{l}\text { Rather hazy and } \\
\text { not adhered to in } \\
\text { many cases. Govt. } \\
\text { mandate takes } \\
\text { precedence over } \\
\text { efficiency criteria. }\end{array}$ & $\begin{array}{l}\text { Clear criteria adhered } \\
\text { to mostly. }\end{array}$ \\
\hline
\end{tabular}




\begin{tabular}{|l|l|l|l|}
\hline & \multicolumn{1}{|c|}{ USA } & \multicolumn{1}{c|}{ CHINA } & \multicolumn{1}{c|}{ BRAZIL } \\
\hline $\begin{array}{l}\text { Incubator } \\
\text { Success Criteria }\end{array}$ & $\begin{array}{l}\text { Incubators not run } \\
\text { entrepreneurially with } \\
\text { clear performance } \\
\text { measures. }\end{array}$ & $\begin{array}{l}\text { Not clear. } \\
\text { Incubator } \\
\text { operations heavily } \\
\text { subsidized by } \\
\text { govt., negating the } \\
\text { need for self- } \\
\text { sustainability. }\end{array}$ & $\begin{array}{l}\text { Performance } \\
\text { measures stated } \\
\text { clearly and clear } \\
\text { attempts by many to } \\
\text { achieve self- } \\
\text { sustainability. }\end{array}$ \\
\hline $\begin{array}{l}\text { Incubator } \\
\text { Management } \\
\text { Capability }\end{array}$ & Strong & Weak & Strong \\
\hline Role of Govt. & $\begin{array}{l}\text { Low - supportive, but } \\
\text { not dictatorial. }\end{array}$ & $\begin{array}{l}\text { High - Visible } \\
\text { hand. }\end{array}$ & $\begin{array}{l}\text { Visible, carrot and } \\
\text { stick, synergistic } \\
\text { approach. }\end{array}$ \\
\hline $\begin{array}{l}\text { Role of } \\
\text { University }\end{array}$ & Active & $\begin{array}{l}\text { Passive, yet } \\
\text { responsive and } \\
\text { innovative. }\end{array}$ & Very active \\
\hline Role of Industry & Active & Passive & Active \\
\hline $\begin{array}{l}\text { Institutional } \\
\text { Environment }\end{array}$ & $\begin{array}{l}\text { Strong institutions of } \\
\text { capitalism. }\end{array}$ & $\begin{array}{l}\text { Weak, but } \\
\text { developing, } \\
\text { institutions. }\end{array}$ & $\begin{array}{l}\text { Developing } \\
\text { institutional } \\
\text { environment. }\end{array}$ \\
\hline Culture & Risk taking & Risk averse & Risk averse \\
\hline
\end{tabular}




\section{References}

Aernoudt, R. 2002. Incubators: Tool for entrepreneurship? Small Business Economics, 23: 127-135.

Almeida, M. 2005. The Evolution of the Incubator Movement in Brazil. International Journal of Technology and Globalization, 1(2), 258-277.

ANPROTEC Panorama 2006. http://www.anprotec.org.br/secaopanorama.php. As of July 25, 2007.

Bhide, A.V. 2000. The origin and evolution of new businesses. (New York: Oxford University Press).

Global Entrepreneurship Monitor: Entrepreneurship in Brazil - 2003. National Report. Abridged Version, English. http://www.gemconsortium.org/download.asp?fid=416. Accessed August 15, 2007.

Chandra, A., and He, W. 2008. "Government Involvement and Financial Service Intensity: A Comparative Study of Three Business Incubators in China,” International Journal of Innovation and Learning.

Chandra, A., He, W., and Fealey, T. 2007. "Business Incubators in China: A Financial Services Perspective," Asia Pacific Business Review, 13(1), 79-94.

Chen, J., Yin, J., \& Zhu, M. 2003. Business incubators in China. International Journal of Entrepreneurship and Innovation Management, 3(1/2), 67-77.

Coutinho, L. and Ferraz, J. 1995. Estudo da Competividade da Industria Brasileira. Rio de Janeiro, Papirus. Cited in Almeida 2005.

Ekholm, T., and Haapasalo, H. 2002. Commercializing innovations-European incubator scene and incubators in evolving markets in the $21^{\text {st }}$ Century. Paper presented at the $12^{\text {th }}$ Nordic Conference on Small Business Research, University of Kuopio, Finland. May 26-28.

Etzkowitz, H., Mello, J., and Almeida, M. 2005. Towards “meta-innovation” in Brazil: The evolution of the incubator and emergence of the triple helix. Research Policy, 34, 411-424.

Grandi, A., \& Grimaldi, R. 2004. Evolution of incubation models: Evidence from the Italian incubation industry. Industry and Higher Education, 23-31.

Guerrera, F. 2005. China's banks smarten up as they switch from state control to commercial lending. Financial Times, June 20: 9. 
Hansen, M. T., Chesborough, H. W., Nohria, N. \& Sull, D. N. 2000. Networked incubators: Hothouses of the new economy, Harvard Business Review, 78(5), 7484.

Harwitt, E. 2002. High technology incubators: Fuel for China's new entrepreneurship? China Business Review, 29(4), 26-29.

Hoeser, Utz, Business Incubation in Argentina 2003. Paper presented at the ICSB Conference 2003, Belfast.

Kantis, H. 2005 Initiatives For Fostering Entrepreneurial Development. In Developing Entrepreneurship: Experience in Latin America and Worldwide. Inter-American Development Bank Fundes Internacional. 111-118.

Knopp, L. 2007. Across state lines: U.S. incubators report how state governments support business incubation. NBIA Review, 23(4), 6-9.

Konana, P., Doggett, J. N. \& Balasubramanian, S. 2005. Advantage China. Frontline, $22(6), 1-15$.

Kuratko, D. F. \& LaFollette, W.R. 1986. Examining the small business incubator explosion. Mid-American Journal of Business, 1(2), 29-34.

Lalkaka, R. 2003. Business incubators in developing countries: Characteristics and performance. International Journal of Entrepreneurship and Innovation Management, 3(1/2), 31-55.

Lalkaka, R. 2002. Technology business incubators to help build an innovation-based economy. Journal of Change Management, 3(2), 167-176.

Lalkaka, R., Feng-Ling, M., \& Lalkaka, D. 2000, Rapid growth of business incubation in China. Paper presented at International Conference on Business Incubation, (Shanghai, China).

Lalkaka, R. and Shaffer, D. 1999. Nurturing Entrepreneurs, Creating Enterprises: Technology Business Incubation in Brazil. International Conference on Effective Business Development Services. Rio de Janeiro, Brazil, March 2-3.

Ma, F. 2004. Incubators in China \& the development of private sector. Presentation at Global Forum on Business Incubation, New Delhi, Oct. 14-19.

Mytelka, L. and F. Farinelli. 2003. "From local clusters to innovation systems," in Systems of Innovation and Development: Evidence from Brazil. New Horizons in the Economics of Innovation. Eds. Cassiolato, J.E., H.M.M. Lastres, M.L. Maciel., Edward Alger: UK. 
NBIA. 2005. What is Business Incubation?

http://www.nbia.org/resource_Centre/what_is/index.php, as of May 25.

Scaramuzzi, E. 2002. Incubators in developing countries. infoDev Program. The World Bank, 1-54.

Smilor, R. W., Gibson, D. V. \& Dietrich, G. B. 1990. University spin-out companies: Technology start-ups from UT-Austin. Journal of Business Venturing, 5, 63-76.

Torch Center. 2003. China Torch Program. Torch High Technology Industry Development Center, Ministry of Science and Technology, Beijing, People’s Republic of China.

Zedtwitz, M.V. 2003. Classification and management of incubators: Aligning strategic objectives and competitive scope for new business facilitation. International Journal of Entrepreneurship and Innovation Management 3(1/2): 176-196. 